Revista Complutense de Historia de América

ISSN: $1132-8312$

http://dx.doi.org/10.5209/RCHA.56874

\title{
Las relaciones entre Costa Rica y España: de la tensión en la ONU a la normalización del vínculo diplomático (1946-1953)
}

\author{
Carlos Sola Ayape
}

Recibido: 8 de octubre de 2015 / Aceptado: 27 de junio de 2016

Resumen. Tras la reapertura del caso de la controvertida Spanish question, aquel mayo de 1949 fue un mes especialmente intenso para los delegados de las Naciones Unidas. A propuesta de cuatro países latinoamericanos, se pusieron en cuestionamiento las resoluciones condenatorias que pesaban sobre el gobierno del general Franco desde diciembre de 1946. En esta coyuntura, que dejó entrever las grandes diferencias de criterio entre los países miembros, la posición de Costa Rica estuvo envuelta en una fuerte polémica, ante la indisciplina de sus delegados en la ONU y las grandes fracturas existentes en el seno de la Junta de Gobierno, así como entre ésta y el nuevo presidente electo Otilio Ulate (1949-1953). Sin embargo, la nueva presidencia fue determinante para la normalización plena de las relaciones entre Costa Rica y España, que culminó con la firma de un tratado de amistad perpetua en 1953.

Palabras clave: Relaciones hispano-costarricenses; Spanish question; Naciones Unidas; régimen franquista; Alberto Martín Artajo; Benjamín Odio; José María Cavanillas; Otilio Ulate; siglo XX.

\section{[en] The Relations between Costa Rica and Spain: from the United Nations Tension to the Normalization of the Diplomatic Liason (1946-1953)}

\begin{abstract}
After the reopening of the Spanish question controversial case, in May 1949 were it was a special and intense month for the delegates of the United Nations. At the suggestion of four Latin-American countries, the condemnatory resolutions were questioned over the Franco regime coming from December 1946. Within this conjuncture, where the controversies were exhibited among the participating countries, the posture of Costa Rica was involved in a strong polemic in front of the disobedience of its UN delegates, as well as the existing fractures in the Junta de Gobierno and among this and the new elected president Otilio Ulate (1949-1953). Nevertheless, the new presidency was a determining factor for the overall regularization of the relations between Costa Rica and Spain, which culminated with the signature of an agreement of perpetual friendship in 1953.
\end{abstract}

Keywords: Relations Hispanic-Costa Rica; Spanish question; United Nations; Franco regime; Alberto Martin Artajo; Benjamin Odio; Jose Maria Cavanillas; Otilio Ulate; 20th Century.

Sumario. 1. La ONU ante la Spanish question: a modo de introito. 2. La propuesta conjunta en la ONU de Brasil, Bolivia, Colombia y Perú en 1949. 3. La postura de Costa Rica ante la propuesta del cuatripartito latinoamericano. 4. España ante la actitud de Costa Rica en la ONU. 5. La normalización de las relaciones entre Costa Rica y España: a modo de final. 6. Referencias bibliográficas.

Tecnológico de Monterrey, Escuela de Humanidades y Educación, Vicerrectoría de Investigación, Posgrados y Educación Continua (México)

E-mail: csola@itesm.mx 
Cómo citar: Sola Ayape, C., (2017), Las relaciones entre Costa Rica y España: de la tensión en la ONU a la normalización del vínculo diplomático (1946-1953), en Revista Complutense de Historia de América 43, 307-331.

Lo que parece es que a la Delegación le dio el berrinche por decir que no y que no. ¡Lo qué habrá pensado de nosotros el Brasil, mirando este juego de niños en que la cancillería les dice a sus representantes que hagan las cosas de un modo y los representantes deciden hacerlas de modo contrario! ${ }^{2}$.

\section{La ONU ante la Spanish question: a modo de introito}

En un enrarecido contexto histórico, condicionado por un acechante nazi-fascismo en Europa, la Guerra Civil española (1936-1939) trajo tres importantes consecuencias que marcaron el devenir de los años siguientes y no sólo en lo que a España se refiere: primera, el triunfo en el campo de batalla de un "bando nacional" capitaneado por el general Francisco Franco; segundo, la inmediata gestación de un régimen político manu militari que duraría casi 40 años y, tercera, y entre otras más, la imposición de la victoria franquista al bando republicano por medio de una severa represión física y cultural, donde no faltó la condena al exilio de esos republicamos que, paradojas del destino, corrieron con la "fortuna" de abandonar su patria y encontrar refugio en países como Costa Rica.

Muy pronto, el devenir de los acontecimientos puso de manifiesto que aquel conflicto español tenía muy poco de civil y mucho de militar y que, lejos de ser una guerra exclusivamente fratricida, alcanzó una dimensión internacional desde el momento en que la Alemania nazi, la Italia de Mussolini y la Unión Soviética de Stalin se hicieron presentes apoyando a los bandos enfrentados. No se oculta, en consecuencia, que la Segunda Guerra Mundial, la misma que vio su fin con el sobrecogedor desastre nuclear de Hiroshima y Nagasaki en agosto de 1945, empezó precisamente en aquella España del 18 de julio de 1936.

Desde esta perspectiva, hay que recordar que, en junio de 1945, la Conferencia de San Francisco fue el escenario elegido, donde, a propuesta de la delegación mexicana encabezada por Luis Quintanilla, se sentenció que el ingreso a este nuevo organismo internacional debía quedar vetado para aquellos candidatos cuyos regímenes políticos hubieran sido establecidos "con la ayuda de las fuerzas militares" que habían luchado contra las Naciones Unidas y, además, "mientras que estos regímenes permanezcan en el poder"3. A pesar de que el contenido de la nota no daba para más, estaba claro que detrás de tal formulación se encontraba la España de Franco, tal y como, así resultó ser. En pocas palabras, la comunidad internacional llegó a decir en San Francisco, y así sería ratificado en Londres o Potsdam ${ }^{4}$, que el régimen franquis-

Otilio Ulate Blanco, Diario de Costa Rica, 15-V-1949, 9.

Sobre la iniciativa mexicana en la Conferencia de San Francisco, véase Sola Ayape, 2009: 153-159; 2016b: 321377. Sobre la estrecha vinculación entre México y la élite política del exilio español, véase Serra - Mejía - Sola, 2014: 380. También sobre la trayectoria diplomática de México hacia la Segunda República Española, exilio incluido, véase Sola Ayape 2016.

4 En efecto, en la Conferencia de Potsdam, celebrada entre el 17 de julio y el 2 de agosto de 1945 en las proximidades de Berlín, los tres grandes -la Unión Soviética, el Reino Unido y los Estados Unidos- proclamaron que no apoyarían ninguna solicitud de admisión del gobierno de Franco a cualquier organismo internacional 
ta vigente en España desde 1939 presentaba claras concomitancias con el derrotado nazi-fascismo y que el general Franco venía comandando una España conquistada por la fuerza de las armas, gracias al apoyo de los desaparecidos Hitler y Mussolini ${ }^{5}$.

Por eso, el triunfo aliado sobre el totalitarismo, principalmente, sobre la Alemania nazi, fue determinante para marcar el proceso de gestación de aquel mundo de posguerra. La creación de la Organización de las Naciones Unidas, a imagen y semejanza de la Sociedad de las Naciones -organismo internacional creado en 1919 en el marco de la firma del Tratado de Versalles tras la primera gran guerra-, fue determinante para encauzar los designios de un mundo conmocionado por la tragedia de la guerra más espantosa que la humanidad había conocido hasta la fecha.

A partir de entonces, la llamada Spanish question siempre estuvo presente en la mesa de discusión de las Naciones Unidas, dividiendo a la comunidad internacional entre partidarios y detractores. Elocuentes fueron aquellas palabras del delegado polaco cuando advirtió sin titubeos que "el problema de la España de Franco es y ha sido una piedra de toque en nuestras convicciones democráticas" ${ }^{\text {. }}$. Aun siendo esto cierto, metafóricamente hablando la ONU tapiaba las puertas para el ingreso de España en este organismo internacional, una decisión que quedaba condicionada al cambio de régimen político, siempre y cuando éste se diese al abrigo de los principios democráticos. A su vez, dos medidas de la Asamblea General marcaron el futuro inmediato de las relaciones de los Estados miembros con esta España en dictadura: la primera, aquella resolución condenatoria del 12 de diciembre de 1946 y, la segunda, la del 17 de noviembre de $1947^{7}$. Descartadas posiciones de fuerza mayor para acabar con el régimen franquista -intervención armada o imposición de un bloqueo económico y comercial-, se acordaron por el contrario otras de carácter más simbólico y, a la postre, no demasiado efectivas, que tan bien quedaron retratadas en aquel entrecomillado del diario francés Le Monde: "Con alfilerazos no se mata el toro" . $\mathrm{Si}$ en la primera de ellas se instaba formalmente a los países miembros a retirar sus ministros y embajadores de Madrid, en la segunda era la Asamblea la que depositaba su confianza en el Consejo de Seguridad, principal órgano rector de la ONU, para que asumiera "sus responsabilidades conforme a la Carta, tan pronto como estime que la situación respecto a España lo exige".

A la postre, el tiempo demostró que la lentitud acabaría condicionando la evolución de los procesos administrativos y resolutivos, como un claro y contundente síntoma de la poca, o más bien nula, voluntad política que tenían las dos grandes potencias -los Estados Unidos y la Unión Soviética- de abordar a fondo el problema español. El asunto quedó visto para su sentencia final desde el momento en que el coloso americano se percató del papel geoestratégico que podía desempeñar la España franquista en el devenir de la Guerra Fría, más aún después de que el general Franco presumiera ante propios y extraños de ser el centinela de Occidente y el primer gran gendarme en librar con éxito la batalla en suelo europeo contra el expansionismo comunista. Con estos antecedentes, así bosquejados, una proposición de cuatro países

vinculado con las Naciones Unidas por sus implicaciones con el derrotado nazi-fascismo.

Sobre la morfología del régimen franquista, véase en otros Preston, 1994; Tusell, 1996, 373; Moradiellos, 2002;

Saz, 2004; Molinero - Ysás, 2008; Aróstegui, 2012.

Naciones Unidas, 1950a: 395-405.

Sobre esta coyuntura histórica véase, entre otros, Portero, 1989; Lleonart y Amsélem, 1977; Pons Ràfols, 2005.

Le Monde, 16-XII-1946, 4.

Véase Naciones Unidas, 1947: 11. 
latinoamericanos vino a recuperar la discusión sobre el manido problema español, con el fin de acabar de una vez con las resoluciones condenatorias vistas más arriba ${ }^{10}$.

\section{La propuesta conjunta en la ONU de Brasil, Bolivia, Colombia y Perú en 1949}

En la dilatada espera del Consejo de Seguridad para acordar medidas coercitivas en contra de la España del general Franco, la mencionada resolución del 12 de diciembre de 1946 se convirtió en un punto de fricción y de desencuentro entre la comunidad internacional representada en el organismo neoyorkino ${ }^{11}$. Como era previsible, desde muy pronto comenzó a aflorar la necesidad de anteponer la preeminencia de los intereses nacionales sobre los internacionales. En palabras del delegado colombiano, Roberto Urdaneta Arbeláez, ya desde 1947 comenzaron a "surgir importantes divergencias" en la Asamblea General, porque "era evidente" que el régimen de Franco, "cualquiera que hubiesen sido sus simpatías por el Eje", no constituía para ese entonces "una amenaza para la paz" ni tampoco "un foco de inquietud internacional"12. No en vano, el 28 de mayo de 1948 fue la fecha elegida para que los Estados Unidos restablecieran sus relaciones financieras con la España franquista ${ }^{13}$. Así, las concesiones hechas a Franco, tales como el envío de embajadores, la admisión de España en las Naciones Unidas o los préstamos, eran el precio que había que pagar "por la realización de los planes militares agresivos de los Estados Unidos en España"14.

Dadas así las cosas, la primavera de 1949 fue especialmente activa en la ONU en materia de discursos y de discusiones en torno al controvertido asunto español. En clara señal de refrendo, y como buena prueba de ello, fue la intensa actividad desplegada por parte del servicio exterior de Franco, destacando sobremanera el protagonismo de sus diplomáticos en determinados centros estratégicos del extranjero como lo fueron Washington, Roma, París o, como se verá a continuación, San José de Costa Rica ${ }^{15}$. En juego estaba no sólo la anulación de la mencionada resolución de diciembre de 1946, sino el comienzo del deshielo diplomático. Recordemos que

10 Sobre los pormenores y no pocos diferendos de los países latinoamericanos en torno a la Spanish question en la ONU, véase Sola Ayape, 2015.

11 En materia de diagnósticos, y a expresa recomendación de la Asamblea General de la ONU (9 de febrero de 1946), el Consejo de Seguridad sí se tomó la molestia de hacer una investigación entre mayo y junio de ese año, a través de un sub-comité nombrado para tal misión. El informe final fue contundente al subrayar, entre otras valoraciones, que, "en origen, naturaleza, estructura y conducta general, el régimen de Franco es un régimen de carácter fascista, establecido en gran parte gracias a la ayuda recibida de la Alemania nazi de Hitler y de la Italia fascista de Mussolini”. Véase, por ejemplo, Diario de Costa Rica, 15-V-1949, 10.

12 Naciones Unidas, 1949b: 86-91.

13 En aquel marco de discusión, sorprendieron las declaraciones del secretario de Estado estadounidense, Dean Acheson, posicionándose en favor de la resolución dictada contra Franco y mostrándose partidario de que el gobierno de Franco concediese "al pueblo español ciertas libertades fundamentales antes de que España pueda ser aceptada como una potencia mundial", sobre todo, el derecho de Habeas Corpus, los tribunales libres y la libertad de cultos. Y esto así, ante las acusaciones a los Estados Unidos de mantener acuerdos militares con Franco. De hecho, el 16 de mayo, el delegado estadounidense tuvo que comparecer ante la Asamblea para negar que su país tuviera convenio militar "de ninguna especie" con Franco y para reiterar que la política de los Estados Unidos, respecto a España, no había cambiado. La Nación, 12-V-1949, 1 y Diario de Costa Rica, 13-V-1949, 6.

14 Palabras del delegado polaco en las Naciones Unidas, Katz-Suchy, con fecha de 4 de mayo de 1949. Naciones Unidas, 1949a: 79-82. Sobre las relaciones y acuerdos militares entre los Estados Unidos y España, véase Chamorro, 1976.

15 Sobre la política exterior española durante el franquismo, véase entre otros Viñas, 1979; Pereira, 1982; Calduch, 1994; Pardo, 1995; Beneyto - Pereira, 2015. 
el 6 de abril del mismo, el ministro de Asuntos Exteriores español, Alberto Martín Artajo, remitió desde Madrid un comunicado al encargado de negocios de España en Washington, con el fin de solicitarle noticias "sobre [la] reunión [de] países hispano-americanos, que me llegan por otro conducto, en que por unanimidad, con sólo reservas iniciales de Méjico, Panamá y Uruguay, decidieron apoyar [la] propuesta Brasil que, según mis noticias, debe ser presentada [el] sábado". En el mismo se decía también que el ministro de Negocios Extranjeros de Colombia iba a actuar "directamente a favor España"16.

Ese mismo día, el ministro Artajo escribió también al embajador de España en Río de Janeiro -con copia a José María Cavanillas, ministro de la legación de España en Costa Rica-, compartiéndole una información confidencial, según la cual la propuesta de Brasil iba a merecer dos tercios favorables de los votos, y además coincidía, según manifestaciones recientes del encargado de Negocios de los Estados Unidos, "con cálculo del Gobierno americano". De este modo, y atendiendo a dicha estimación, se contemplaba que los países que habrían de votar por la "propuesta española" eran los siguientes: Brasil, Estados Unidos, Colombia, Argentina, Santo Domingo, Bolivia, Ecuador, Perú, Nicaragua, Honduras, Paraguay, El Salvador, Líbano, Siria, Egipto, Turquía, Irak, Afganistán, Costa Rica, Venezuela, Filipinas, Grecia, Holanda, Pakistán, Yemen, Arabia Saudita, Australia, Canadá, China, Etiopía, Irán, Siam, Suecia, Liberia, Haití, África del Sur. En cuanto a los "dudosos abstenidos o favorables de última hora": Inglaterra, Nueva Zelanda, Noruega, Dinamarca, Islandia, Bélgica, Luxemburgo, Birmania, Cuba y Chile. En el grupo de los "dudosos contrarios": Francia, México, Panamá, Guatemala, Indostán, Uruguay. Y, por último, los "contrarios": Polonia, Rusia, Checoslovaquia, Yugoslavia, Rusia blanca y Ucrania ${ }^{17}$.

Como valoración final, el ministro Artajo enfatizó, en su señalamiento "muy confidencialmente", que aparecían como dudosos Islandia, Luxemburgo, Cuba y Chile, "que todas probabilidades hacen aparecer como favorables ya hoy" y que aparecían como "dudosos contrarios" Francia, Panamá, Méjico y Uruguay, "que probablemente se abstendrán". Por tanto, y con el fin de agotar el cúmulo de posibilidades, el ministerio de Asuntos Exteriores español dio inicio a una campaña diplomática encaminada a hacer "gestiones con países dudosos", con el fin de conseguir que, "si no pueden obtener [el] voto favorable, se ausenten [en el] momento [de la] votación, para que su presencia o abstención no pueda ser computada para los dos tercios" ${ }^{\prime 18}$.

Secundando esta maniobra diplomática, al día siguiente, 7 de abril, de nuevo Artajo escribió un comunicado confidencial al embajador de España en la Santa Sede, ordenando que se cursaran "instrucciones telegráficas urgentes al delegado apostólico [en] Washington para influir con ministro de Negocios Extranjeros [de] Francia en sentido favorable [a] España". A su vez, se informaba que casi la mayoría de los países, "con la reserva única de Panamá y Méjico, la totalidad de los árabes

16 Comunicado de Alberto Martín Artajo al encargado de negocios de España en Washington. Madrid, 6-IV-1949. Archivo General de la Administración [España] [en adelante AGA], Asuntos Exteriores, caja 82/6957.

17 En los prolegómenos de la votación, el periódico La Nación se hizo eco de los sondeos, que informalmente habían hecho las delegaciones de los países miembros, donde se presentía "una batalla decisiva entre los que favorecen y los que se oponen al levantamiento del boicot diplomático contra el régimen franquista que aprobó la ONU en 1946". La Nación, 15-V-1949, 3.

18 Comunicado de Alberto Martín Artajo al embajador de España en Río de Janeiro. Madrid, 7-IV-1949. AGA, Asuntos Exteriores, caja 82/6957. 
y varios europeos, así como los Estados Unidos especialmente", iban a apoyar la propuesta de Brasil para anular la disposición de la ONU que obligaba a la retirada de embajadores y ministros de Madrid. También se hacía hincapié en el hecho de que el Consejo de Ministros de Francia se estaba ocupando del asunto, aunque "sin entrar a fondo", dejándolo todo a la discreción del ministro de Negocios Extranjeros que, además, presidía la delegación gala en las Naciones Unidas. Las últimas líneas del comunicado de Artajo tuvieron el siguiente viso de advertencia: "Ministro [de] Negocios Extranjeros está bien dispuesto hacia España, pero sufre influjo [de] elementos socialistas. Por ello, [la] intervención [del] delegado apostólico puede ser decisiva"19.

Con estos preliminares y hasta estratagemas de negociación diplomática para lograr la obtención del mayor número de votos en favor de la causa española, se presentó ante los miembros de la Asamblea General de la ONU un proyecto de resolución conjunta, impulsado a la par por Brasil, Bolivia, Colombia y Perú, para dejar vacío de contenido la condenatoria del 12 de diciembre de 1946. En cuanto a su contenido, la propuesta del cuatripartito latinoamericano se articuló en torno a un corpus argumentativo, sustentado sobre la base de cinco consideraciones básicas, a saber:

Primera: Que la propuesta presentada en el segundo período de sesiones de la Asamblea General de la ONU en 1947, que tenía por objeto la confirmación de la resolución del 12 de diciembre de 1946 sobre el régimen político en vigor en España, no obtuvo la aprobación de las dos terceras partes de los votos requeridos.

Segunda: Que esta "votación negativa" de 1947 fue interpretada por ciertos gobiernos como una "derogación virtual" de la cláusula que, en la anterior resolución, recomendaba la retirada de jefes de las misiones diplomáticas que tuvieron rango de embajador o ministro plenipotenciario ante el gobierno español.

Tercera: Que, en vista de las dudas acerca del "buen fundamento" de tal interpretación, otros gobiernos se abstuvieron de acreditar jefes de misiones diplomáticas ante el gobierno de Madrid y que por este hecho se ha producido una "desigualdad en detrimento de ellos".

Cuarta: Que la resolución de 1946 no estipulaba la ruptura de relaciones políticas y comerciales con el gobierno de España, lo que ha dado lugar a "acuerdos bilaterales" entre varios miembros de las Naciones Unidas con el gobierno de Madrid, y

Quinta: Que los gobiernos que tomaron en cuenta la recomendación del 12 de diciembre de 1946, se hallaban colocados en posición de desigualdad y que, en consecuencia, "operan en desventaja" de aquéllos que son "económicamente más débiles".

Y, por último, y teniendo como aval este caudal de argumentos, el proyecto de resolución del cuatripartito hacía la propuesta de "dejar a las naciones miembros de las Naciones Unidas en entera libertad de acción en lo que se refiere a sus relaciones diplomáticas con España" ${ }^{20}$. De este modo, y en palabras de Alberto Lleonart, la propuesta de este grupo de países latinoamericanos pretendía estimular las relaciones diplomáticas de España, "a fin de que cada Estado se libere de las cargas que pesaban sobre él, dimanantes de la resolución de 1946"21.

19 Comunicado de Alberto Martín Artajo al embajador de España en la Santa Sede. Madrid, 7-IV-1949. AGA, Asuntos Exteriores, caja 82/6957.

20 Lleonart y Amsélem, 1985: 145-147.

21 Ibídem: 55. 
En resumen, tan sólo tres años después de la resolución condenatoria de la ONU y a una década del triunfo del general Franco en la Guerra Civil española, la propuesta del cuatripartito ponía en evidencia, primero, que esta resolución no era cumplida de forma íntegra y cabal por todos los miembros de la ONU y, segundo, que el incumplimiento de una disposición común venía generando un trato desigual en materia de relaciones diplomáticas entre ciertos Estados soberanos con aquél al que llamaban el "gobierno de Madrid".

Por consiguiente, la resolución condenatoria del 12 de diciembre del 46 volvía a ponerse sobre la mesa de debate, después de no lograr su ratificación en 1947. Por tanto, y ante la arbitrariedad y la falta de disciplina a la hora de cumplir íntegramente con el contenido de las resoluciones de la ONU, se abría la posibilidad, secundando la pauta de otros países, de abrir la puerta para que cada uno de los Estados miembros pudiera formalizar sus relaciones diplomáticas y comerciales con la España franquista.

Fuera de la disciplina de la ONU, o cuando menos de una forma discrecional, países con importantes variaciones en el sesgo político de sus respectivos gobiernos, tal y como fue el caso de Costa Rica, acabaron modificando su tradicional postura con respecto a la España de Franco. No así, por ejemplo, el caso de México, donde el régimen presidencialista posrevolucionario había convertido el "caso español" en un asunto ajeno a variaciones presidenciales y sexenales, definiéndose sin remilgos como un régimen frontalmente contrario a la dictadura franquista ${ }^{22}$.

\section{La postura de Costa Rica ante la propuesta del cuatripartito latinoamericano}

El 16 de mayo de 1949 fue la fecha elegida para proceder a la votación en torno a la propuesta del cuatripartito latinoamericano encabezado por Brasil. Como se viene diciendo, en juego estaba la pertinencia de dejar en libertad a los países miembros de la ONU para enviar a sus representaciones diplomáticas a Madrid y, en consecuencia, entablar un nivel de entendimiento formal con el gobierno de Franco. Efectuada la votación, el balance final fue de 26 votos a favor y 15 en contra, registrándose en consecuencia una de las mayorías más altas logradas en la Asamblea, claro síntoma del nivel de interés y hasta de expectación que había generado la propuesta. Del grupo de países latino-americanos, 12 de ellos votaron a favor -Brasil, Colombia, Bolivia, Argentina, Ecuador, El Salvador, República Dominicana, Honduras, Paraguay, Nicaragua, Perú y Venezuela-, y cuatro en contra: Guatemala, México, Panamá y Uruguay. Finalmente, la oposición del bloque de países soviéticos, comandado desde Moscú, acabaría decidiendo la suerte de la propuesta del cuatripartito, que finalmente no pudo salir adelante por cuanto se necesitaban dos más para alcanzar los dos tercios de los votos requeridos. Y, precisamente, y junto a Cuba, uno de esos dos faltantes, por ausencia de su delegado, fue el de Costa Rica ${ }^{23}$.

A este respecto, hay que decir que, más allá del libre ejercicio soberano, la posición de Costa Rica frente al caso español acabó atrapada en un particular juego

Al respecto, véase Sola Ayape, 2008 y 2011.

23 En efecto, y como destaca Alberto Lleonart, "la votación ante la Asamblea General: 26 a favor, 15 en contra, 16 abstenciones. [...] Costa Rica que votó en contra, ausente ahora. Por tanto, el proyecto de resolución no fue aprobado por no reunir los dos tercios de la mayoría”. Lleonart y Amsélem, 1985: 147. 
de tribulaciones políticas que, como se verá a continuación, llegó a implicar a su delegado en la ONU, al ministro de Relaciones Exteriores, al resto de los miembros integrantes de la Junta de Gobierno y, finalmente, al propio presidente electo ${ }^{24}$. De entrada, aquello parecía estar fuera del previsible guion, por cuanto quedaba en entredicho la política de congruencia que el país venía desempeñando a favor del caso de España en las Naciones Unidas. Del bloque latinoamericano -y conjuntamente con Argentina, Ecuador, El Salvador, República Dominicana y Perú-, Costa Rica había sido uno de los países que votó en contra de la resolución 39 (I) del 12 de diciembre de 1946, por la que se excluía a España de la comunidad internacional y se la sometía a un bloqueo diplomático y político ${ }^{25}$. Asimismo, y un año después, también emitió su voto en contra de la resolución del 17 de noviembre de 1947, donde no sólo se reafirmaba la anterior, sino donde la Asamblea General depositaba "su confianza en que el Consejo de Seguridad asumirá sus responsabilidades conforme a la Carta, tan pronto como estime que la situación respecto a España lo exige". Para entonces, Costa Rica ya se había convertido en un abanderado frente a cualquier medida que se pretendiese adoptar en contra de España, asumiendo a todas luces "un papel claro de obstruccionismo"26.

A decir verdad, y ya en mayo del 49, aquellos días previos a la votación en las Naciones Unidas fueron especialmente tensos e intensos, donde no faltaron algunas maniobras carentes de la esperada congruencia y hasta de la previsible disciplina política. Como destacó en portada el Diario de Costa Rica, "tema de palpitante actualidad nacional e internacional ha sido en estos últimos días y sigue siéndolo, el de la posición de la Junta de Gobierno frente el caso de España"27. Así en la ONU, así durante el conflicto español, ya que, como advirtió Ángel María Ríos, la guerra de España había aparecido "como un fantasma" que deambularía por la vida social y política costarricense para producir "reacciones contradictorias"28.

En aquellos momentos de tanta tensión e incertidumbre, el 16 de mayo, y en su calidad ministro de la legación de España en Costa Rica, José María Cavanillas escribió al ministro de Asuntos Exteriores, Alberto Martín Artajo, haciéndole llegar una puntual presentación de los últimos hechos ocurridos ${ }^{29}$. Aquella "maniobra", tal

24 Por momentos, aquello era reflejo de la complejidad política de la Costa Rica del momento. Recordemos que tras la guerra civil José Figueres y Otilio Ulate formalizaron un acuerdo el $1^{\circ}$ de mayo de 1948 que, en palabras de Héctor Pérez, "enmarcó la vida política del país durante los años siguientes”. Por el mismo, se decidió que una Junta Revolucionaria -finalmente presidida por Figueres- gobernaría el país sin Congreso legislativo durante 18 meses y que, a su término, Ulate, del Partido Unión Nacional (PUN), asumiría la presidencia por cuatro años. En octubre de 1949, la Junta convocó elecciones para diputados con el fin de conformar la asamblea legislativa correspondiente al periodo presidencial de Ulate. Los resultados arrojaron un contundente triunfo del PUN de Ulate, dejando en evidencia el poco apoyo ciudadano con que contaba la Junta. El 7 de noviembre de 1949 quedó promulgada la nueva Constitución y al día siguiente Otilio Ulate se hacía cargo de la presidencia de la República. Pérez Brignoli, 1997: 130 y 142.

25 Lleonart y Amsélem, 1991: 71 y 84.

26 Ibídem: 85.

27 Y se añadía lo siguiente: "Tiene extraordinaria importancia el caso, porque alrededor del mismo ha habido puntos de vista opuestos, incluso en la orientación de la política internacional del ministerio de Relaciones Exteriores". También este mismo periódico advirtió de la presencia en el país de dos posturas encontradas: "Por una parte, hay motivo de simpatía hacia la República, por lo que atañe a la posición democrática de aquélla en concordancia con la democracia nuestra. Cuestión de principios. Por otra parte, son analizados los puntos de vista de la política internacional de tipo continental. Cuestión de relaciones entre las naciones". Diario de Costa Rica, 14-V-1949, 1.

28 Ríos, 1997: 69.

29 Despacho de José María Cavanillas a Alberto Martín Artajo. San José de Costa Rica, 16-V-1949. AGA, Asuntos Exteriores, caja 82/6957. 
y como la catalogó de inicio, se había caracterizado "por una cantidad de circunstancias agravantes que la hacen más abyecta" y que era fruto de una "premeditación, alevosía, abuso de autoridad, conminación, dolo y hasta nocturnidad". A su entender, "toda la trama" había sido "urdida tenebrosamente" de la forma siguiente y con los rasgos que a continuación se presentan:

1. La Junta de Gobierno aprovechó "la intempestiva ausencia" de San José, tanto del presidente José Figueres como del presidente electo Otilio Ulate, ambos de gira "de interés político" en la provincia de Guanacaste desde el sábado 7 de mayo.

2. Del 9 al 12 de mayo, Benjamín Odio, en su calidad de ministro de Relaciones Exteriores, se mantuvo "en la brecha, luchando prácticamente solo y con denuedo, frente a los embates de todos sus compañeros que, coaligados en desatada ofensiva, trataban de salvar y respaldar la postura insostenible de abierta rebelión y de auténtica felonía en que aparecían colocados los delegados Cañas y Valverde", a la sazón, los delegados de Costa Rica en la Asamblea en la ONU.

3. El viernes 13 de mayo, a primeras horas de la tarde, se produjo el regreso del presidente Figueres a la capital costarricense, quien convocó de inmediato a su gabinete ministerial. La reunión se caracterizó "por su índole auténticamente borrascosa", debido, tal y como era previsible, a las posiciones encontradas en torno al asunto español: de una parte, y manteniendo "su posición noble y leal de respeto a la palabra dada y a la firma repetidamente empeñada", se encontraba el ministro Odio, apoyado y respaldado, "aunque débilmente -sin la autoridad, energía y decisión indispensables- por el presidente Figueres, a quien no podía escapársele la gravedad y trascendencia del tema"; de la otra, y en el "bando opuesto", el resto de ministros, "con excepción del de Seguridad Pública, buen amigo de España, que se halla al margen de las reuniones de la Junta y solamente interviene en ellas cuando deben tratarse asuntos de su propio Departamento". Dadas así las cosas, y en favor y defensa de los "delegados rebeldes" -Alberto Cañas y Emilio Valverde-, llevaron la voz cantante los Sres. Valverde y el Sr. Oduber, este último, secretario general de la Junta, con voz y voto en ella.

4. El resultado de la votación fue contundente, con siete votos contra dos -los del presidente Figueres y el ministro Odio-, en el sentido de rectificar "las instrucciones que el día 10 había enviado a los delegados de Costa Rica el canciller Odio" y, en consecuencia, de respaldar oficialmente "el voto negativo" que aquéllos dieron el sábado 7 y ordenar a sus delegados a emitirlo "igualmente negativo" en la sesión plenaria de la Asamblea.

5. Ante lo sucedido, el presidente Figueres, "ya en última instancia y consciente de la gravedad de la situación", logró convencer al bloque mayoritario de la necesidad de consultar la decisión de la Junta al nuevo presidente electo, principalmente por la provisionalidad en la que se encontraba el gobierno, ya que sólo le restaban cinco meses por delante antes de que Otilio Ulate tomase el 
mando ejecutivo ${ }^{30}$. En palabras del ministro Cavanillas, "aunque no de buena gana, hubo de aceptarse este trámite dilatorio y requerido al efecto el Sr. Ulate, quien prometió pronunciarse al siguiente día, sábado 14 "31.

6. A las ocho de la mañana del 14 de mayo, y con previa solicitud de audiencia, el presidente electo Ulate se entrevistó durante más de hora y cuarto con el ministro de España en Costa Rica, quien le entregó "notas cruzadas entre la legación y el ministerio de Relaciones de Costa Rica". Al término de la reunión, Ulate se entrevistó también con el embajador de los Estados Unidos en San José para conocer su opinión al respecto ${ }^{32}$.

7. Ese mismo 14 de mayo, el presidente electo remitió una carta al presidente de la Junta de Gobierno -cuyo contenido se analizará a continuación-, mostrándose favorable a la propuesta del cuatripartito latinoamericano con respecto al caso español y, en consecuencia, de liberar las trabas que presentaba la ya comentada resolución del 12 de diciembre de 1946.

Ante esta concatenación de hechos, lo más paradójico de todo estaba en el hecho de que la problemática española ya contaba con discusiones y decisiones previas en el seno de la propia Junta de Gobierno costarricense. En efecto, para este entonces ya existía una serie de antecedentes resolutivos, donde Costa Rica había dejado constancia de su posición favorable a la presencia de ministros y embajadores extranjeros en Madrid. Así lo hizo en noviembre de 1948, cuando la Junta de Gobierno, a través de la cancillería, ordenó al delegado Alberto Cañas que votara a favor en la Asamblea General, en ese entonces con sede en París, con motivo de la moción presentada por Argentina, "para el levantamiento de la interdicción diplomática española acordada en el año de 1946"33.

Asimismo, recuérdese también que el 29 de marzo de 1949 desde la Casa Amari-

$30 \quad$ En titular y en portada, el periódico La Nación escribía lo siguiente: "El lunes definirá la Junta de Gobierno el voto de Costa Rica en el caso de España. Ha sido consultado el señor Presidente Electo don Otilio Ulate". La Nación, 15-V-1949, 1.

31 El periódico falangista español Arriba se posicionaba sobre el particular con un artículo publicado en portada a principios de mayo de 1949, dedicando todo un panegírico a los dos presidentes costarricenses. Reconocía que Costa Rica era un pequeño país pero "moralmente una gran nación”, por haber alzado en América "la bandera de una buena política". Del presidente Figueres se decía que era un "hombre de relieve excepcional y no sólo para Costa Rica, sino para el amplio conjunto de los pueblos". También destacó como ejemplar la constante colaboración entre Figueres y Ulate, "única que en estos graves tiempos de crisis política y social puede salvar la paz de Costa Rica". Así, y si Figueres era "un político noble y sincero, aureolado por la victoria y por un patriotismo sin límites", Ulate era "el hombre consagrado por la unanimidad casi completa del cuerpo electoral, expresada ahora sin trampas ni coacciones". Ambos eran "hombres capaces" que merecían ser "bien conocidos y apreciados por la nación española, para quien tan grato es siempre el progreso y la felicidad de sus hijas de América". En resumen, España recordaba que "América había producido allí dos políticos ejemplares, dos corazones generosos y dos figuras de dimensión excepcional, cuyos hechos hacen que Costa Rica ocupe un puesto insigne en la comunidad hispánica”. Arriba, 4-V-1949, 1. El artículo fue reproducido íntegramente en Diario de Costa Rica, 11-V-1949, 5.

32 Resumen del despacho ${ }^{\circ} 139$, de 16 de mayo de 1949, enviado por el ministro de España en San José de Costa Rica. Madrid, 27-V-1949. AGA, Asuntos Exteriores, caja 82/6957.

33 Eran palabras del presidente electo Otilio Ulate en una carta que, como se verá más adelante, fue publicada en Diario de Costa Rica, 15-V-1949. Y, sin embargo, en este entonces el delegado Cañas se abstuvo de votar, tal y como reconocería el propio canciller Odio. La Nación, 5-VI-1949, 1. A este respecto hay que decir que el propio embajador Cañas hizo un balance de tu trayectoria diplomática en un libro intitulado Ochenta años no es nada. Del mismo se desprende que su salida como embajador en la ONU no se debió a este polémico episodio, sino que el fin de sus funciones ya se había decidido antes. Véase Cañas, 2008. 
lla se había enviado una nota al ministro de España en Costa Rica, donde se le comunicaba de la decisión de la Junta de Gobierno de instruir a su delegado en la ONU "en el sentido de votar la revocatoria de la resolución que recomendó, en el año 1946, el retiro de los Jefes de Misiones Diplomáticas acreditadas en España", aunque con una conditio sine qua non: "Que no existan informes o estudios valederos para la ONU que hagan recomendable el mantenimiento de dicha resolución"34.

Por último, el 10 de mayo de 1949, en una nota "más categórica", el ministro Benjamín Odio le escribió personalmente al representante diplomático español en Costa Rica compartiéndole lo siguiente: "[...] me es honroso hacer del conocimiento de su Excelencia que hoy he cablegrafiado a nuestro delegado ante las Naciones Unidas para que, al ser conocido el asunto por la Asamblea General, vote la derogatoria de la resolución del año 1946" "35. En efecto, Odio escribió a su delegado Cañas el siguiente y hasta breve dictado: "Sírvase votar en Asamblea a favor de [la] revocatoria de resolución 1946"36. He aquí, por tanto, la extrañeza del ministro español Cavanillas y la razón de su comentario cuando se refería a que había sido contravenida "la posición noble y leal de respeto a la palabra dada y a la firma repetidamente empeñada" ${ }^{37}$.

No obstante, y para ese entonces, la delegación diplomática de Costa Rica en la ONU ya había esgrimido en varias ocasiones razones de "orden moral" para oponerse al levantamiento del aislamiento diplomático impuesto al régimen franquista, de ahí su primer voto en contra en la Comisión Política, "interpretando equivocadamente las instrucciones de la Cancillería" ${ }^{38}$. De hecho, la orden de la Cancillería del 10 de mayo de 1949, para que se apoyase la propuesta del cuatripartito en la sesión plenaria de la Asamblea, fue respondida por la delegación presentando sus motivos "para interpretar como interpretó las instrucciones recibidas sobre el caso, y pidió que se tuviera en cuenta la situación personal de los delegados" 39 . Finalmente, y como apostilla Sáenz Carbonell, "la Cancillería no dio respuesta alguna, y entonces la delegación se dirigió a la Junta Fundadora para que ésta considerase el asunto. La Junta, desautorizando implícitamente al Canciller Odio, decidió dar instrucciones a los delegados para que se abstuviesen de votar acerca de la moción" ${ }^{*}$.

\subsection{Las intervenciones del presidente electo Otilio Ulate}

34 La Nación, 5-VI-1949, 1. El referido Arriba reconocía que en 1946 Costa Rica no había votado "contra la resolución injusta de la ONU" y que dicha votación contraria había quedado refrendada "con las públicas declaraciones de su ministro de Relaciones Exteriores, hechas en París, cuando se dirigía a la apertura de la III Asamblea de las Naciones Unidas". Estos "buenos servicios" hacían que la Madre Patria tuviera "una gran dosis de admiración" hacia aquella "pequeña Atenas del Istmo" y que los lazos entre las dos naciones fuesen "estrechos e imperecederos", y que para "los corazones españoles haya siempre, para este ilustre pueblo americano, un lugar de excepción”. Arriba, 4-V-1949, 1.

35 La Nación, 5-VI-1949, 1.

36 La Nación, 5-VI-1949, 6.

37 "El hecho fue aquí en Costa Rica motivo de la intervención, amistosa desde luego, del ministro español, que se sintió extrañado del voto del delegado de Costa Rica, toda vez que ya él había sido informado acerca del procedimiento que debía de seguirse en las Naciones Unidas". Diario de Costa Rica, 11-V-1949, 6. Al respecto, se llegó a justificar la actitud contradictoria del delegado en la ONU "a un mal entendimiento en las comunicaciones cruzadas", algo que llevó al delegado Cañas a votar "contra el criterio que sobre el particular sustenta la Junta de Gobierno". Diario de Costa Rica, 11-V-1949, 1.

38 Ministerio de Relaciones Exteriores de Costa Rica, 1949: 24 y 25.

39 Ibídem.

40 Sáenz Carbonell, 2013: 29 y 30. 
En efecto, ante tales preliminares y siguiendo con la secuencia de acontecimientos, el 14 de mayo de 1949, a dos días de someterse a votación en la Asamblea de la ONU la propuesta del cuatripartito latinoamericano, el presidente electo Otilio Ulate, y a petición expresa del embajador de Costa Rica en Honduras -que le sugirió posicionarse con respecto a la problemática española en su condición de futuro presidente del país-, remitió una carta al todavía presidente de la Junta de Gobierno, José Figueres, con copia dirigida a dos de sus ministros: el de Relaciones Exteriores y el de Justicia y Gracia. La particularidad residió en el hecho de que aquella epístola también quiso editarla en el periódico Diario de Costa Rica para elevarla al rango de conocimiento público. El titular elegido para la ocasión no podía ser más expresivo: "Don Otilio Ulate se pronuncia sobre la posición de Costa Rica en el caso de España"41. La batalla dialéctica estaba planteada en el pórtico de la prensa nacional y poniendo a la sociedad costarricense como testigo principal.

Hay que decir que, unos días antes, y de manera verbal, el presidente electo ya se había comunicado con el presidente Figueres, instándole a conocer "su criterio en el particular". Seguidamente, la respuesta a tal petición se hizo a través de Gonzalo Solórzano, indicándole que el presidente de la República estaba convencido de la necesidad de apoyar la proposición de Brasil y, por consiguiente, de dejar sin efecto alguno la recomendación condenatoria del 12 de diciembre de 1946 que instaba a la inmediata retirada de los representantes diplomáticos de Madrid. Empero, Ulate no ocultó su desconcierto tras conocer el arbitrario comportamiento de los delegados costarricenses en la ONU -quienes habían votado en contra de la propuesta del cuatripartito en el Comité político ${ }^{42}$, por cuanto "no pueden existir dos corrientes en la Junta que Usted preside, porque se daría el caso insólito de que el jefe de Gobierno y su ministro de Relaciones Exteriores tuvieran opinión contraria a la política exterior de su propio gobierno o, a la inversa, que éste fuera en dirección contraria a la de su presidente y a la del canciller". Así apuntado, el voto negativo de Costa Rica en el Comité político de la ONU estuvo impregnado de estas contradicciones, algo que tanto recordó a aquella advertencia de Oscar Aguilar Bulgarelli: "La política costarricense posterior a 1950 ha girado alrededor de los acontecimientos ocurridos en la anterior década" ${ }^{43}$.

Como se dice, la necesidad de Ulate de volver a consultar al presidente Figueres se hizo esta vez por medio epistolar, después de conocer el día anterior -13 de mayolos "puntos de vista opuestos entre sí" de los ministros de Relaciones Exteriores y de Justicia y Gracia: señores Odio y Facio, respectivamente ${ }^{44}$. De nuevo, el punto toral estuvo centrado en las “instrucciones precisas” que el ministerio de Relaciones

${ }_{41}$ Diario de Costa Rica, 15-V-1949, 1 y 10. El ministro Cavanillas remitía también esta carta, para la ocasión de manera mecanografiada, al ministro de Asuntos Exteriores español, Alberto Martín Artajo. Despacho de José María Cavanillas a Alberto Martín Artajo, San José de Costa Rica, 17-V-1949. AGA, Asuntos Exteriores, caja $82 / 6957$.

42 Unos días antes de someterse a deliberación en la Asamblea, el Comité político de la misma había aprobado la resolución latinoamericana, recomendando, en consecuencia, suavizarse "la exclusión contra España". El voto fue de 25 votos a favor y 16 en contra, absteniéndose países como los Estados Unidos, Gran Bretaña o Francia. En espera de la votación en la Asamblea, este comité resolvió que los miembros de las Naciones Unidas debían gozar de "libertad de acción con respecto a sus relaciones diplomáticas con España". De la comunidad latinoamericana, tan sólo Costa Rica, Guatemala, México y Panamá votaron en contra. Diario de Costa Rica, 8-V-1949, 1-2. También La Nación, 8-V-1949, 4.

43 Aguilar Bulgarelli, 1969: 13.

44 En efecto, la postura del ministro de Justicia y Gracia, Gonzalo Facio, era la de mantener "la falta de relaciones diplomáticas con el gobierno de Franco". La Nación, 14-V-1949, 1 y 9. 
Exteriores -"órgano normal de la conducción de esas relaciones con los gobiernos extranjeros"- había dado el 10 de mayo no sólo de "votar en favor de la proposición brasileña", sino del compromiso "de carácter internacional con el gobierno español, que no puede razonablemente dejar de cumplirse"45.

Ulate se preguntaba cómo lograría explicarse una determinación de última hora en contra, cuando la propia Junta de Gobierno ya había manifestado su posición en favor de España desde noviembre de 1948, tal y como se ha explicado más arriba. En materia de argumentaciones, recordó que desde la Casa Amarilla se habían pedido explicaciones al delegado en la ONU, quien simplemente "se limitó a hacer referencia de los informes que determinaron la propia recomendación de 1946". Sin embargo, Ulate no encontró "en los documentos que tengo a la vista ningún estudio o informe", en el sentido de que hiciesen aconsejable mantener la recomendación del año 1946. Por consiguiente, y más aún después de los acuerdos de la Junta de Gobierno en favor de España, "no puede nuestra Delegación acogerse a este informe de dos años antes para inducirla a rectificaciones".

Desmontada la base argumentativa del delegado costarricense en la ONU, el presidente electo Ulate tenía claro que, frente a la demagogia que se estaba haciendo en la prensa, la posición de Costa Rica sobre el asunto español no se planteaba en términos dialécticos -franquismo o antifranquismo, totalitarismo o democracia, "como se pretende hacer creer" ${ }^{46}$-, por cuanto el éxito de la propuesta del cuatripartito, liderado por Brasil, no tenía por qué levantar "las sanciones establecidas contra el régimen político español en las recomendaciones de 1946, sino que simplemente dejaría en libertad a los países que son miembros de las Naciones Unidas para tener o no tener representantes diplomáticos en Madrid, según les plazca"47.

Para Ulate, y lejos de llevar la polémica a un debate maniqueo entre régimen franquista o república española, Costa Rica estaba en su derecho de votar -"si quiere"- la proposición brasileña sin que se altere o modifique la posición que tenga o quiera tener con el régimen español ${ }^{48}$. Y esto así, porque, a su entender, la recomendación de la ONU venía resultando "totalmente inoperante en la práctica y está en desuso, y el Brasil ha querido acomodarse a la realidad internacional". Así, "ninguna nación sujeta sus relaciones con el régimen político de España a la recomendación de las

45 Diario de Costa Rica, 15-V-1949, 1 y 10. De hecho, el propio Diario de Costa Rica, forzado por su propietario, el presidente electo Ulate, se vio en la obligación de sacar una nota de prensa aclaratoria con este significativo titular: "Casa de herrero, cuchillo de palo", donde en su encabezado decía lo siguiente: "La nota de don Otilio Ulate al Jefe del Gobierno la publicó este Diario con una montaña de errores que hacen confuso e ininteligible su texto". Diario de Costa Rica, 17-V-1949, 5.

46 El mismo Diario de Costa Rica hacía referencia a esta aparente dialéctica en los términos siguientes: "En resumen de cuentas, hoy en la mañana quedará definida la situación de Costa Rica con respecto al gobierno de España: con Franco y contra la República o con la República y contra el régimen franquista". Diario de Costa Rica, 14-V-1949, 6.

47 En este punto, el presidente electo Ulate se apoyaba en una nota que el propio delegado de Costa Rica en la ONU remitió a su canciller en estos términos: "Conoce el señor Ministro la determinación de Brasil de presentar un proyecto de resolución en esta Asamblea, que dejaría sin efecto la recomendación apuntada, aunque sin derogar la condenatoria hecha en contra del actual régimen de España".

48 Recordemos que tres de aquellas recomendaciones que la Asamblea General de las Naciones Unidas hacía el 12 de diciembre de 1946 eran, primera, la exclusión del gobierno español como miembro de los organismos internacionales establecidos por las Naciones Unidas o que tengan nexos con ellas; segunda, el rechazo a participar en conferencias u otras actividades que puedan ser emprendidas por las Naciones Unidas o por otros organismos y, tercera, la necesidad de que el Consejo de Seguridad estudiase las medidas necesarias para remediar la situación, siempre y cuando no se estableciese en España dentro de un tiempo razonable un gobierno cuya autoridad emanase del consentimiento de los gobernados y que se comprometiera, entre otros, a respetar la libertad de palabra, de culto y de reunión. 
Naciones Unidas, sino que cada una resuelve su conducta según las conveniencias de su política internacional o los intereses de su política comercial".

En este sentido, Ulate quiso recordar que la ONU estaba conformada por alrededor de 70 países, pero que había resultado "verdaderamente absurdo tratar de imponerles un patrón para sus relaciones con España, como si todas tuvieran los mismos intereses e iguales aspiraciones" ${ }^{\prime 49}$. En consecuencia, y de presidente a presidente, Ulate recomendaba a Figueras que echase "al saco sus escrúpulos, si los tiene, como yo he echado los míos", ya que las relaciones oficiales con países no democráticos "no implican quebrantamiento de los principios que Ud. y yo sustentamos en cuanto al ejercicio de la democracia en el mundo". Para ilustrar su recomendación ponía el ejemplo de los Estados Unidos e Inglaterra que mantenían embajadores en la Rusia del soviet, "cuyo gobierno es de un tipo tan monstruosamente totalitario como lo fueron el de la Alemania nazista y el de la Italia fascista" ${ }^{50}$. Por eso, y si en la Asamblea de las Naciones Unidas "nos juntamos con la URSS y con los Estados satélites, que más que satélites son sus esclavos para defender la democracia contra el totalitarismo, $¿$ en qué papel vamos a quedar?" Finalmente, Ulate terminaba con un último interrogante: "El criterio que se le quiere aplicar a Franco, ¿no es aplicable por los mismos motivos a Stalin?"51.

Con estas preguntas, donde en su formulación estaban implícitamente las respuestas, el presidente electo Ulate daba por concluida su extensa carta sobre el posicionamiento de Costa Rica con respecto al asunto español, haciendo una última alusión a la particular discriminación que se venía haciendo "arbitrariamente de los regímenes no democráticos del otro lado del mar", tal y como, en su opinión, se hacía en "nuestra América conforme a cada uno le conviene, porque todo es según el color del cristal con que se mira". De ahí que, en su opinión, y reafirmando su convicción democrática y su respeto a la autodeterminación de los pueblos, la Junta de Gobierno no debía modificar la posición que, en noviembre de 1948, había tomado en favor de España, "mientras no se den motivos para el cambio". Dicho de otro modo, Costa Rica debía dar su voto favorable a la propuesta del cuatripartito latinoamericano.

A tenor de lo sucedido, esta larga exposición de motivos que presentó el presidente electo en su carta personal al presidente Figueres pareció no tener efecto alguno. Ni sus recomendaciones ni las del canciller Odio sirvieron para que la delegación de Costa Rica diera su voto a favor de la propuesta del cuatripartito en la Asamblea. Según fuentes del ministerio de Asuntos Exteriores español, "la maniobra continuó en el seno de la Junta, con el propósito de que la resolución se tomase demasiado

49 Razón no le faltaba al presidente electo Otilio Ulate. Los casos más destacados eran los de los Estados Unidos y Gran Bretaña que, si bien no tenían embajadores en Madrid, sí al menos poseían encargados de negocios con el objeto de vertebrar una política comercial -por no hablar de una diplomacia encubierta- con la España franquista. Al igual, países como Bolivia, Paraguay, Egipto y Líbano, que habían votado a favor de la resolución del 12 de diciembre del 46 o se abstuvieron de hacerlo, habían restablecido posteriormente sus relaciones diplomáticas con la España de Franco.

50 Y añadía para la ocasión: "Los mantienen aún ahora que existe un estado de conflicto potencial entre esas naciones que puede ser mañana una nueva y de las más sangrientas guerras de la historia. Y, sin embargo, nadie les cobra pecado contra la democracia por el hecho de que mantengan esas relaciones oficiales ni nadie les pide que retiren a sus embajadores".

51 Contra pronóstico, aunque fiel al pragmatismo del momento, la URSS fue cómplice del ingreso de la España franquista en la ONU en diciembre de 1955, entre otros motivos, para ejercer un control y una supervisión en la sombra en torno a las particulares relaciones militares entre España con los EEUU. En palabras de José María Areilza, en ese entonces embajador español en Washington, "fue una propuesta de la Delegación soviética la que hizo que nuestro país se convirtiera en Estado miembro de las Naciones Unidas”. Areilza, 1974: 240 y 244. 
tarde para poder ser comunicada a los delegados de la ONU, e incluso parece que alguno de los ministros avisó a aquéllos para que estuviesen ausentes de la reunión de la Asamblea" ${ }^{, 2}$.

En efecto, y en la misma línea, aquel 16 de mayo, día de las votaciones en la ONU, José María Cavanillas escribió desde San José a Alberto Martín Artajo, atestiguando que "todas las incidencias ocurridas a lo largo de la pasada semana" habían culminado "con la ausencia de la delegación de Costa Rica" 53 . En su opinión, y a pesar del "contundente y aleccionador mazazo de D. Otilio Ulate" -en clara alusión a la carta recién presentada-, la Junta continuó con su plan preconcebido y "la conjura prosiguió implacable y los conjurados, desentendiéndose de todo escrúpulo y apelando a los más desacreditados ardides, emplearon la táctica retardataria y obstruccionista", para que la decisión de la Junta, conforme a las recomendaciones del presidente electo, "no tuviese lugar hasta que fuese ya demasiado tarde" y las órdenes "no pudieran llegar a tiempo a los delegados en la ONU". Su conclusión a este respecto la presentaba con estas palabras: "No es preciso ser un lince para deducir que, antes de la decisión adoptada esta tarde por la Junta de Gobierno, alguno de los señores ministros debió asumir la iniciativa de telefonear o cablegrafiar a aquellos dos delegados, aconsejándoles aprovechasen la tarde para dar un paseo" ${ }^{54}$.

De hecho, al día siguiente de la votación en la ONU, y sin tiempo para la demora, de nuevo Otilio Ulate se hizo presente en los medios de comunicación para ser especialmente crítico con la delegación de Costa Rica en la ONU, dejando en evidencia pública la gravedad de lo ocurrido. Al respecto, y en el mencionado informe de Cavanillas a Artajo, con fecha de 16 de mayo, el primero hacía énfasis en el sentido de que el presidente electo Ulate Blanco "no dejaría pasar, sin la adecuada réplica, el desaire de que su magnífico pronunciamiento sobre la cuestión española [...] ha sido objeto por parte de esta Junta de Gobierno, la cual, con la inconsistencia que la caracteriza, ha hecho caso totalmente omiso de la irrebatible tesis y de las conclusiones que se desprenden del precipitado pronunciamiento". A su vez, informaba que la réplica del Sr. Ulate no se había hecho esperar sino unas horas, "y su acerada pluma de gran periodista se revela una vez más en el editorial 'Desairada la posición internacional de Costa Rica", que, a cuatro columnas, publicaba en "su propio periódico" (Diario de Costa Rica), "sin estridencias de tono ni extemporáneos gestos de teatral dramatismo". Así, y siguiendo con la narración del informe del ministro Cavanillas, el presidente electo, "con donosa intención serio-humorística", había lanzado "la más cerrada e irrebatible requisitoria contra las insensateces de este Gobierno, al que deja materialmente al desnudo, echándole en cara más, mucho más de cuanto nuestro gobierno o esta legación podrían correctamente atreverse a

$52 \quad$ Resumen del despacho ${ }^{\circ} 139$, de 16 de mayo de 1949, enviado por el ministro de España en San José de Costa Rica. Madrid, 27-V-1949. AGA, Asuntos Exteriores, caja 82/6957.

53 Despacho de José María Cavanillas a Alberto Martín Artajo. San José de Costa Rica, 16-V-1949. AGA, Asuntos Exteriores, caja 82/6957.

54 En palabras de Cavanillas, "sólo a las dos de la tarde -esto es, cuando atendida la diferencia de horario entre Costa Rica y New York el asunto estaba más que votado- merced a la apremiante y casi conminatoria exigencia del Sr. ministro de Relaciones, se han reunido por fin -y sólo 'pro-forma'- estos señores de la Junta de Gobierno, acordando por mayoría enviar instrucciones a los delegados Cañas y Valverde, en el sentido de abstenerse en la votación plenaria”. Finalmente, la delegación costarricense figuró como ausente en el recuento final en la Asamblea. Despacho de José María Cavanillas a Alberto Martín Artajo. San José de Costa Rica, 16-V-1949. AGA, Asuntos Exteriores, caja 82/6957. 
decirle" ${ }^{55}$.

Ciertamente, en un editorial del Diario de Costa Rica, intitulado "Desairada posición internacional de Costa Rica" 56 , el nuevo presidente electo -después de reconocer que había habido en la Asamblea "una decidida inclinación en favor de la tesis brasileña"- lamentaba sin embargo que la mayoría en la votación no se había podido obtener, en buena medida por la actitud de Costa Rica, "cuya delegación estuvo ausente, quedando nuestro país en un desairada posición internacional" y también la propia República por quedar "apartada del bloque latino-americano que propiciaba la propuesta de Brasil".

Tras esta primera valoración, el presidente electo Ulate dirigió sus críticas hacia la Junta de Gobierno, ya que, en asuntos de política internacional, "deberían marcarse fija y responsablemente los caminos", porque no se puede estar "vacilando cuando se está dentro de un concierto de naciones en el cual se establece necesariamente un estado de conciencia que lleva implícito el juicio internacional sobre cada uno de los miembros que integran el conjunto". Huelga decir que, a su entender, el nuevo presidente del país anunciaba con claridad cuáles iban a ser sus intenciones en cuanto a su futura política exterior.

Desde las páginas impresas de su periódico, el propio editorialista recordó cómo, en una sesión de noviembre de 1948, la Junta había tomado el acuerdo "de girar instrucciones a su delegado para que votase en favor de la moción, presentada en aquella época por la República [de] Argentina para hacer cesar los efectos de la recomendación para el retiro de embajadores y ministros de Madrid"57. Seis meses después de aquello, la Junta volvió a confirmar y renovar dichas instrucciones, "cuando la proposición ya no era argentina, sino brasileña" y, a pesar de lo cual, "la delegación se declara en rebeldía y vota contra el criterio de su propio gobierno". En consecuencia, el presidente electo se preguntaba cómo habría de explicar esta anómala situación no sólo la Junta de Gobierno, sino también los miembros de la delegación costarricense en la $\mathrm{ONU}^{58}$.

Así, y en palabras del presidente electo Ulate, "nadie sabe lo que pasó entonces entre bastidores. Presumiblemente, la delegación se negó por segunda vez, porque tampoco se sabe cuáles motivos dieron lugar a que no quedaran firmes las instrucciones del ministro Sr. Odio y a que el asunto fuera considerado de nuevo en el gobierno, ni por iniciativa de quién, porque ya era cosa terminada". Por consiguiente,

$55 \quad$ El ministro Cavanillas terminaba su informe con la siguiente valoración, a modo de loa al autor: "Seguro estoy de que el editorial de referencia -cuyo texto me honro de acompañar- ha de merecer, tanto por su contenido en sí, como por la alta y responsable figura de su autor, la más placentera atención de V. E.”. Despacho de José María Cavanillas a Alberto Martín Artajo. San José de Costa Rica, 16-V-1949. AGA, Asuntos Exteriores, caja $82 / 6957$.

56 Diario de Costa Rica, 17-V-1949, 5.

57 Recordemos que durante la Asamblea General de las Naciones Unidas, que se celebró en París desde septiembre a diciembre de 1948, Gonzalo J. Facio Segreda fue el delegado interino de Costa Rica por enfermedad del ministro de Relaciones Exteriores, el Lic. Odio. Después, y a su paso por New York, hizo a la prensa declaraciones favorables a España, donde aseguró que llevaba instrucciones terminantes del gobierno de Costa Rica de votar afirmativamente la moción de Colombia y Argentina para el levantamiento de la interdicción diplomática que pesaba contra España.

58 El presidente electo Ulate estaba convencido de que la opinión pública costarricense se iba a preguntar sobre el valor y la credibilidad de las comunicaciones oficiales que el ministro de Relaciones Exteriores habría de dirigir las representaciones diplomáticas de los países extranjeros si, según se ha visto, "no tiene autoridad para mandarlas y si los subalternos desacatan sus instrucciones". Para terminar con esta reflexión no exenta de ironía: "La misma opinión se sentirá tentada de decirle a la Junta, sin encono, antes de bien jovialmente, como el maestro de escuela a sus alumnos: ¡Niños, más formalidad!”. 
todo parecía indicar que a la delegación le había dado "el berrinche por decir que no y que no".

Las últimas valoraciones de Ulate estuvieron relacionadas con las futuras implicaciones de aquel "juego de niños" en las relaciones de Costa Rica con la comunidad internacional y, en especial, con los países vecinos. He aquí sus palabras: “iLo qué habrá pensado de nosotros el Brasil, mirando este juego de niños en que la cancillería les dice a sus representantes que hagan las cosas de un modo y los representantes deciden hacerlas de modo contrario!". En síntesis, Ulate llegaba a la conclusión, después de analizar pormenorizadamente los hechos, que Costa Rica había pasado "por todas las etapas imaginables en un asunto de carácter internacional, en el cual, según parece, todavía no se ha formado criterio". Esas cuatro etapas habían sido las siguientes: primero, resolver que se votase favorablemente; segundo, votar negativamente; tercero, pronunciándose por la abstención y, cuarta, quedarse ausente. Sus palabras finales tuvieron el presente nivel de elocuencia: "No creemos que a ningún otro país de la tierra le haya ocurrido cosa semejante en una asamblea internacional" 59 .

\subsection{La posición del canciller Benjamín Odio}

El 6 de junio de 1949, José María Cavanillas escribió al ministro Artajo sobre las "interesantísimas declaraciones del Sr. ministro de Relaciones acerca de la política hispano-costarricense con relación al reciente incidente sobre el caso español". Así, daba cuenta de que el canciller Odio le había comunicado "hace pocos días" que, en caso de continuar "la violenta campaña de prensa y opinión" desatada con motivo de la "reciente inconcebible actuación" de la delegación de Costa Rica en la ONU frente al caso de España, se iba a ver en la necesidad de acudir a la prensa, "haciendo en ella públicas y muy terminantes declaraciones". Y esto así, porque le parecía "muy triste, y alcanzaba ya a lo intolerable, que todas las críticas y censuras lloviesen sobre su departamento y sobre su propia persona", cuando él estaba libre de culpas, ya que "en todo momento y hasta el último momento" había mantenido y defendido la tesis del "recíproco respeto a los gobiernos que los pueblos quisieran darse, de la inviolabilidad de la palabra empeñada de Gobierno a Gobierno y, en fin y como consecuencia, del voto favorable a España que implicaba la propuesta conjunta del Brasil, Perú, Colombia y Bolivia" ${ }^{60}$.

Y, tal y como se lo había adelantado personalmente al ministro de la legación española en Costa Rica, el canciller Benjamín Odio se vio obligado a solicitar a $L a$ Nación la realización de una larga entrevista que fue publicada con el título "La política internacional se debe orientar más de pueblo a pueblo que de que gobierno

59 De hecho, La Nación no encontraba justificación alguna a "tan enconada controversia", salvo por "el empeño de mantener en aislamiento a España en aquellos países que, por estar debajo la influencia soviética, comparten con Rusia el odio a España, odio nacido de que no es en la actualidad la península ibérica un baluarte comunista, bien valioso, por cierto, para el expansionismo soviético". De ahí su incomprensión por "la vacilación en cuanto al voto de Costa Rica", después de la "clara exposición del señor ministro de Relaciones Exteriores". La Nación, $14-\mathrm{V}-1949,9$.

60 El ministro Odio también le confesó a José María Cavanillas que se sentía especialmente dolido por "la actitud de hermético silencio de sus compañeros de Gobierno", quienes "no sentían el categórico imperativo de asumir, gallardamente, la parte de responsabilidad, personal o solidaria, que de lo ocurrido les alcanzaba". Despacho de José María Cavanillas a Alberto Martín Artajo. San José de Costa Rica, 6-VI-1949. AGA, Asuntos Exteriores, caja $82 / 6957$. 
a gobierno" con fotografía incluida del entrevistado. En el encabezado, y en letra pequeña y en negrita, una nota que decía lo siguiente: "Texto de un sensacional reportaje del señor Ministro de Relaciones Exteriores, Lic. Don Benjamín Odio, en el que da a conocer todos los antecedentes y documentos que obraron en relación con la actitud de Costa Rica en el caso español"'61.

Además de las confrontaciones internas en el seno de la Junta, el canciller aparecía en este medio de prensa tras haber sido cuestionado por los estudiantes de Derecho $^{62}$ con relación a su postura ante el caso español y, en general, por la "propaganda perversa" que se estaba haciendo en contra de Costa Rica, indicando, "con tintes sombríos", que la Junta de Gobierno estaba formada por "integrantes de una banda de salteadores" y que el país contaba con cárceles atestadas de "presos políticos entre los que se hace, con gran frecuencia, fusilamientos en masa, mientras a las mujeres que opositan nuestro sistema de Gobierno se les pela al rape y se les desnuda en las calles para escarnio propio y de sus familiares". Para Odio, estas acusaciones, producto de "campañas denigrantes y mentirosas", eran realmente resultado de una falacia que, no obstante, pesaban "en el ánimo de quienes las leen sin conocer realmente la realidad nacional que es diametralmente opuesta".

Entrando en detalles, el canciller recordó primeramente que el principio de la política internacional de Costa Rica estaba basada "más de pueblo a pueblo que de gobierno a gobierno". He aquí su testimonio y su nivel argumentativo: "Ni una sola vez se ha apartado la política internacional nuestra de ese principio universal de que las relaciones internacionales se deben orientar de pueblo a pueblo más que de gobierno a gobierno". Y esto así, porque la resolución de la ONU de 1946 en contra de España afectaba, a su entender, "fundamentalmente al pueblo español". De hecho, el gobierno del general Francisco Franco podía importar poco o mucho, pero "el pueblo mismo de España que nos engendró, ha de tener para nosotros, necesariamente una importancia enorme". En consecuencia, Costa Rica debía abstenerse de condenar al régimen franquista, porque "una medida adversa tendría consecuencias muy perjudiciales para el pueblo de España, que es en definitiva lo que debe preocuparnos".

Con respecto al general Franco y al franquismo, el canciller Odio dijo lo siguiente en su entrevista: "La forma política que ese régimen tiene, está para nosotros muy distante de lo que entendemos por gobierno democrático y de opinión pública, y no la consideramos una garantía del ejercicio de la libertad". Sin embargo, y a modo de aditamento, dijo que "por encima de la forma política está el interés del pueblo respectivo, y no es razonable sacrificar ese interés a una divergencia de criterio sobre la forma". Además, recordó que, a lo largo de 12 años, no se había producido "ningún levantamiento popular" en contra de Franco, ni tampoco existía "un estado crónico de inconformidad y resistencia por parte del pueblo"63.

A pesar de que la mayoría de sus compañeros del ejecutivo no compartieron las

\footnotetext{
La Nación, 5-VI-1949, 1 y 6.
}

62 En el informe que José María Cavanillas envió al ministro español Artajo, con fecha de 6 de junio de 1949 , le hacía la siguiente constatación: "Debo creer que las manifestaciones de los estudiantes del último curso de Derecho de esta Universidad [...] del 2 del corriente, han constituido [...] la gota de agua que ha desbordado la paciencia y reserva, hasta ahora mantenidas por este señor Ministro de Relaciones". Despacho de José María Cavanillas a Alberto Martín Artajo. San José de Costa Rica, 6-VI-1949. AGA, Asuntos Exteriores, caja 82/6957.

${ }_{63}$ En realidad, la mayoría de los países latinoamericanos estaban por la labor de revocar la declaratoria de diciembre de 1946 y de dejar que cada país procediese, con respecto a la España franquista, tal y como le conviniese. La Nación, 14-V-1949, 9. 
tesis del ministro Odio, éste quiso hacer públicas en La Nación sus declaraciones con motivo de la reunión de los miembros de la Junta de Gobierno, tal y como fueron transcritas por el secretario de la misma, Daniel Oduber. Éstos fueron sus argumentos, en favor de la proposición de dejar sin validez la polémica resolución del 12 de diciembre de 1946:

1. "Porque existe un acuerdo reiterado de la Junta para que así sea".

2. "Porque la Junta en materia de política internacional ha adoptado como principio el de que debe oírse a los grupos humanos afectados por las situaciones que se debaten".

3. "Porque hace 12 años que Franco gobierna España sin que exista en la cancillería de Costa Rica ningún informe o estudio responsable que demuestre que la voluntad mayorista del pueblo español está contra Franco".

4. "Porque es hora ya de que Costa Rica mantenga en lo internacional un criterio propio desligado de las consecuencias y la propaganda interesada y parcial que apoya a las dictaduras o al comunismo, y adversa o desampara a las democracias según sus conveniencias del momento" ${ }^{64}$.

Finalmente, y para dar por terminada su entrevista, las últimas declaraciones del canciller Odio para La Nación sirvieron para recordar que, a su juicio, la política internacional de Costa Rica, "así como nuestras relaciones y nuestro poder", tenían por destino final "la amistad entre los pueblos y no para con los gobiernos que son transitorios", a pesar de que éstos siempre debían representar, eso sí, "la voluntad de la mayoría del pueblo mismo" ${ }^{65}$.

\section{España ante la actitud de Costa Rica en la ONU}

Más allá de la propuesta en la ONU sobre la controvertida resolución del 12 de diciembre de 1946, no hay duda de que el principal interesado en el regreso de los embajadores a Madrid era el propio gobierno de Franco. Sobre el papel, y de haber prosperado dicha propuesta, España se hubiera asegurado un primer y simbólico paso de acercamiento para que, poco a poco, se fueran abriendo las deseadas puertas de las Naciones Unidas. Por eso, y dadas las particularidades que rodearon al comportamiento de algunos países, uno de los principales actores en el juego de triangulaciones de información fue precisamente el ya mencionado diplomático José María Cavanillas.

Aquel 16 de mayo del 49, el ministro Cavanillas se dio a la tarea de preparar un largo informe que después, y con carácter "muy reservado", remitió a Alberto Martín Artajo, ministro de Asuntos Exteriores español, bajo el tenor siguiente: "Evolución política costarricense durante pasada semana en relación a discusión en la ONU propuesta Brasil". En sus primeras líneas, y sobre "las incidencias aquí ocurridas", daba cuenta de que había culminado, con "la ausencia de la delegación de Costa Rica" en

\footnotetext{
La Nación, 5-VI-1949, 1 y 6.

65 Ibídem.
} 
la votación plenaria de la Asamblea General, la conocida propuesta a favor de España, respaldada por Brasil, Colombia, Perú y Bolivia. En este sentido, enfatizaba en la idea de que el ministro de Relaciones Exteriores de Costa Rica había cursado "claras instrucciones" a sus delegados en la ONU, "ordenándoles rectificar su anterior voto negativo y emitirlo favorable a la propuesta brasileña en la votación plenaria", una medida que parecía ser suficiente para "quedar clara y definitivamente resuelto este apasionante tema".

Y, sin embargo, desde San José, y desde el "propio seno de la Junta de Gobierno" se había ido articulando "la más turbia y artera de las maniobras encaminada a respaldar a aquellos delegados -Sres. Cañas y Valverde- íntimo y admiradísimo amigo el primero de la totalidad de los ministros y hermano, el Sr. Valverde, del propio titular de la cartera de Gobernación”. En su distinción, Cavanillas advertía que Alberto Cañas y Emilio Valverde eran "elementos de ideas más que avanzadas, sectarias, saturados de rencor antiespañol", con especial vinculación al grupo de "amigos de la República española" y al de los "amigos de la Rusia soviética" y, "por si algo faltase en sus respectivas fichas, ambos son muy conocidos hermanos masones". Por añadidura, el ministro español daba cuenta de que los dos señores Valverde -Fernando, ministro de Gobernación- y Emilio -embajador de Costa Rica en Méjico, en íntima relación allí con la embajada soviética y actual delegado segundo de Costa Rica en las Naciones Unidas- habían tenido, "en no muy lejanos días, concomitancias muy estrechas con el comunismo costarricense", habían sido "íntimos amigotes" de líder comunista Mora Valverde -en ese entonces expatriado en México- y, por último, también los "autores intelectuales y materiales del ignominioso asalto y saqueo a los establecimientos comerciales españoles en 1942"66. "En fin -añadía el ministro Cavanillas- para que nada se quede en el tintero, los hermanos Valverde se hallan políticamente vinculados y estrechamente emparentados con nuestro tradicional enemigo Rómulo Betancourt, casado con una prima hermana de aquéllos. Todo se explica, pues, perfectamente" 67 .

Al igual, Cavanillas advertía de "la constante interferencia y decisiva influencia, repetidas veces apuntada en mis informes, del actual régimen de Guatemala en la política costarricense, particularmente con respecto a España". Para ilustrar su tesis, ponía como ejemplo el fallido nombramiento, a mediados de julio de 1948, de Luis Dobles Segreda para el cargo de ministro plenipotenciario de Costa Rica en Madrid, ya que era un "secreto a voces" el "veto inexorable que Guatemala impuso -y sigue imponiendo- contra el envío a Madrid de dicho ilustre Plenipotenciario o de cualquier otro". Asimismo, y tan pronto como fueron conocidas las instrucciones cablegráficas y postales del canciller Odio para que su delegado en Naciones Unidas votase por la propuesta brasileña, el "gobierno filo-comunista de Guatemala" hizo llegar al de Costa Rica "un telegrama cuyos términos implicaban una agria censura y una conminación severa en el sentido de que el voto negativo inicialmente emitido

66 En aquellos días, la prensa costarricense se hizo eco de que los comunistas venían falsificando documentos "para derrotar a España en las Naciones Unidas". También de que algunas radios habían usurpado "ilegalmente la longitud de la onda de Radio Nacional de España para difamar en esa forma a gobiernos amigos del pueblo español" y, por último, de que "gran cantidad de telegramas falsos" habían circulado en los que se suplantaban firmas de embajadores de España dirigidos a cancilleres de países amigos a fin de "producir en ellos una reacción desfavorable". La Nación, 15-V-1949, 1.

67 Despacho de José María Cavanillas a Alberto Martín Artajo. San José de Costa Rica, 16-V-1949. AGA, Asuntos Exteriores, caja 82/6957. Recordemos que Rómulo Betancourt fue miembro del buró político del Partido Comunista Costarricense entre 1931 y 1935. 
[...] en el Comité Político [...] fuese mantenido inexorablemente, a rajatabla, en la votación plenaria. Me consta la existencia de dicho texto telegráfico por quien de él ha tenido oportuna visión" 68 .

Por último, y en el apartado de valoraciones finales, Cavanillas informó a su ministro Artajo que la indignación en Costa Rica era "casi unánime", destacando el disgusto del presidente electo y su enojo "ante el agravio que se le ha inferido al pedirle su informe, haberlo rendido tan luminoso como contundente, para seguidamente echarlo al cesto de los papeles inútiles". Por todo ello, en opinión del ministro de la legación española en San José, el equipo gobernante se hallaba "total y absolutamente desprestigiado, en todos los órdenes, y esta última insensatez ha acabado de hundirle". Este ministro español tildó a la Junta de "gobierno agónico", puesto que nadie creía "en estos señores y todo el mundo cuenta los días que faltan para verlos desaparecer". En cambio, para la causa española se adivinaba un porvenir "infinitamente más risueño", tal y como parecía prometer "la próxima ascensión al poder de D. Otilio Ulate Blanco", quien se había "definido bien claramente en este manoseado y fatigoso tema del 'caso español' y lo ha hecho en forma noble y digna" ${ }^{69}$.

El 27 de mayo, el ministro español de Exteriores, Alberto Martín Artajo, respondió con un comunicado oficial para su ministro en Costa Rica, instándole a que debía "marcar desagrado por actitud delegado Costa Rica", aunque puntualizándole que no convenía acentuar tal hecho, por cuanto, según noticias recibidas desde New York, la actitud del delegado Costa Rica había sido fruto de "su desobediencia a su Gobierno". A pesar de ello, le pedía a su ministro en Costa Rica que debía "insistir en alguna medida disciplinaria contra delegado Costa Rica que dé satisfacción" En cambio, unos días después, el 31 de mayo, el ministro Artajo escribió al embajador de España en París para comunicarle que ni Cuba ni Costa Rica habían votado en contra de España y que, por lo tanto, no se debía aplicar ningún tipo de "criterio restrictivo" $"$.

\section{La normalización de las relaciones entre Costa Rica y España: a modo de final}

A tenor de lo visto en estas páginas, y en el marco una Guerra Fría marcada por la bipolarización, la sede neoyorkina de la ONU se convirtió en uno de los escenarios donde se fue dirimiendo buena parte del destino del régimen franquista. Recordemos para la ocasión que el 4 de noviembre de 1950 fue determinante para la causa de Franco y su "cruzada", ya que ese día la Asamblea General de las Naciones Unidas

68 Despacho de José María Cavanillas a Alberto Martín Artajo. San José de Costa Rica, 16-V-1949. AGA, Asuntos Exteriores, caja 82/6957.

69 Despacho de José María Cavanillas a Alberto Martín Artajo. San José de Costa Rica, 16-V-1949. AGA, Asuntos Exteriores, caja 82/6957.

70 Comunicado de Alberto Martín Artajo a José María Cavanillas. Madrid, 27-V-1949. AGA, Asuntos Exteriores, caja $82 / 6957$.

71 Comunicado de Alberto Martín Artajo al embajador de España en París. Madrid, 31-V-1949. AGA, Asuntos Exteriores, caja 82/6957. Los días de Cañas como embajador costarricense en la ONU estaba contados. En junio de 1949, Daniel Oduber fue nombrado delegado permanente ante la Asamblea General de Naciones Unidas, en sustitución de Alberto Cañas. Véase Joaquín Fernández Alfaro, 1997: 90. Alberto Cañas Escalante era abogado, dramaturgo, novelista y periodista, fue embajador de Costa Rica en las Naciones Unidas de 1948 a 1949 , de 1953 a 1954 y de 1956 a 1958, siendo después viceministro de Relaciones Exteriores y Culto de 1955 a 1956. Sáenz Carbonell, 2013: 91. 
puso fin a la sanciones que desde 1946 venían pesando sobre el gobierno de Madrid, y esto así, bajo la advertencia de que "el establecimiento de relaciones diplomáticas y el intercambio de embajadores y ministros con un gobierno no implica juicio alguno sobre la política nacional de este gobierno"72.

Para la ocasión, y ahora sí, Costa Rica se convirtió en el gran impulsor de esta medida, cuando unos días antes, y conjuntamente con Bolivia, El Salvador, Filipinas, Honduras, Nicaragua, Perú y República Dominicana, presentó un proyecto de resolución a la Asamblea para dejar sin efecto la del 12 de diciembre de 1946, bajo la premisa de que "los organismos especializados de las Naciones Unidas son técnicos y en gran parte no tienen carácter político, y que han sido establecidos en beneficio de los pueblos de todas las naciones y que por lo tanto deben estar en libertad de decidir por sí mismos si es deseable la participación de España en sus actividades"73. Pocos años después, el 14 de diciembre de 1955, y formando parte de un bloque de 16 países, la ONU aprobó el ingreso de España en este organismo internacional. Para la ocasión, países frontalmente contrarios al régimen franquista como el México del PRI se abstuvieron en la votación, esgrimiendo como argumento la preservación del principio de universalidad ${ }^{74}$.

En el terreno bilateral hispano-costarricense, y a tenor de lo visto más arriba, era más que un presagio que la llegada de Otilio Ulate Blanco a la presidencia de la República habría de ser determinante para avanzar en el proceso de normalización plena de las relaciones bilaterales entre Costa Rica y España. Como señaló Sáenz Carbonell, con la administración de Ulate se inauguró una segunda época en las relaciones entre Costa Rica con la España franquista, que duraría desde 1950 hasta la muerte de Franco en noviembre de 1975 y el inicio de la transición democrática española. La política exterior de Ulate estuvo especialmente dirigida a la plena normalización de los nexos con España, respaldando las iniciativas encaminadas a la integración de España en los organismos internacionales. Buena prueba de ello fue el restablecimiento de la legación en España, que estaba clausurada desde 1944, y el nombramiento en febrero de 1950 de Luis Dobles Segreda como ministro plenipotenciario de Costa Rica en España. De igual manera, el gobierno español elevó su Legación en San José a la categoría de Embajada, nombrando como primer embajador a quien hasta entonces había ejercido las veces de ministro en la Legación: José María Cavanillas y Rodríguez. En 1951, el ejecutivo costarricense hizo lo propio con respecto a su Legación en Madrid y designó como primer embajador a Antonio A. Facio Ulloa ${ }^{75}$.

Por último, recordar que el 9 de enero de 1953 Costa Rica y España firmaron un "tratado de amistad perpetua", con el fin de "estrechar aún más los lazos fraternales que unen a los dos países". La firma corrió a cargo de sus respectivos plenipotenciarios: por España, el embajador extraordinario y plenipotenciario, José María Cavanillas y Rodríguez, y por Costa Rica, el ministro de Relaciones Exteriores y Culto, Fernando Lara Bustamante, quien acabaría visitando España ese mismo año por invitación del gobierno de Franco. De su decálogo de artículos, y con esto cerra-

\footnotetext{
También quedó revocada la recomendación que impedía que España fuese miembro de los organismos internacionales establecidos por las Naciones Unidas o que, de una u otra forma, tuvieran vinculación con éstas. Naciones Unidas, 1950b: 18 y 19.

73 Lleonart y Amsélem, 1991: 68, 120, 142 y 153.

74 Sola Ayape, 2014: 157-173.

75 Sáenz Carbonell, 2013: 20; 2000: 20.
} 
mos, conviene destacar dos de ellos. Si en el primero se ratificaba, como expresión de anhelos mutuos, que "habrá paz y amistad perpetua entre la Nación española y la República de Costa Rica", en el cuarto se instaba a que las "altas partes contratantes" debían solucionar "por medios pacíficos cualquier litigio o conflicto, sea cual fuere su naturaleza"76.

A modo de conclusión, y para poner el punto final a estas páginas, es importante significar que las particulares relaciones bilaterales entre Costa Rica y España durante los años siguientes a la Segunda Guerra Mundial -para la ocasión, periodo 19461953-, nos advierten, primero, de un contexto histórico marcado por las diferencias de criterio de los países miembros de las Naciones Unidas a la hora de afrontar la llamada Spanish question, así como por la falta de disciplina y compromiso real a la hora de aplicar congruentemente la resolución condenatoria de diciembre de 1946 en contra del régimen franquista; segundo, la preeminencia de los intereses nacionales -económicos y comerciales, específicamente- a la hora de ponderar la calidad de las relaciones diplomáticas con la España franquista, así como la necesidad de acomodarse y reacomodarse en aquel escenario de guerra fría marcado por los intereses geoestratégicos de las dos superpotencias y, por último, y el caso de Costa Rica es un ejemplo de ello, los giros de la política exterior de los países miembros en función del signo político de sus respectivos gobiernos, en buena medida debido a la ausencia de verdaderas políticas de Estado.

Si la segunda gran guerra se había planteado en términos de enfrentamiento ideológico entre la democracia y el fascismo, la Guerra Fría no abandonaría el juego dogmático y maniqueo, para la ocasión entre democracia versus comunismo. Y para ese entonces, el general Franco ya había presentado a su España como una reserva moral de Occidente y un baluarte de lucha y resistencia en contra del expansionismo comunista en Europa. A la postre, las democracias no tuvieron reparo alguno en manifestar sus connivencias particulares con un régimen político como el franquista, carente de las más elementales credenciales democráticas.

\section{Referencias bibliográficas}

Aguilar Bulgarelli, Óscar. Costa Rica y sus hechos políticos de 1948: problemática de una década. Costa Rica: Editorial Costa Rica, 1969.

Areilza, José María de. Así los he visto. Barcelona: Planeta, 1974.

Aróstegui, Julio (coord.). Franco, la represión como sistema. Barcelona: Flor del Viento, 2012.

Beneyto, José María y Pereira Juan Carlos (dirs.). Historia de la política exterior española en los siglos XX y XXI, II vols. Madrid: CEU Ediciones, 2015.

Calduch, Rafael (coord.). La política exterior española en el siglo XX. Madrid: Edi-

$76 \quad$ El tratado entró en vigor a partir del canje de ratificaciones que fueron hechas en San José de Costa Rica el 11 de febrero de 1954. Véase Ministerio de Asuntos Exteriores de España: 1954. En noviembre de 1956 el nuevo presidente costarricense José Figueres efectuó una visita oficial a España, donde fue recibido en Madrid por el general Franco, visitando también la población ilerdense de Os de Balaguer, de donde eran originarios sus padres. Ese mismo año, ambos países firmaban un convenio cultural que venía a consagrar este nuevo tiempo diplomático entre Costa Rica y España. Véase en Convenio Cultural Costa Rica-España. San José de Costa Rica, 1956. Archivo del Ministerio de Relaciones Exteriores y Culto [Costa Rica], Organismos Internacionales, exp. 7519 . 
ciones Ciencias Sociales, 1994.

Cañas, Alberto F. 80 años no es nada. San José de Costa Rica: Editorial UCR, 2008. Chamorro, Eduardo. Las bases norteamericanas en España. Barcelona: Euros, 1976. Fernández Alfaro, Joaquín Alberto. Oduber: el hombre, el político, el estadista, su pensamiento. San José de Costa Rica: Ed. Universidad Estatal a Distancia, 1997.

Lleonart y Amsélem, Alberto J. 'España y la ONU: la 'cuestión española' (19451950)". Revista de Política Internacional, $\mathrm{n}^{\circ} 152$ (1977), 27-45.

- España y ONU: la cuestión española: documentación básica sistematizada y anotada (tomo III: 1948-1949). Madrid: Instituto Francisco de Vitoria, 1985.

- España y la ONU-IV (1950): la cuestión española. Madrid: CSIC, 1991.

Ministerio de Asuntos Exteriores de España. Tratado de amistad entre el Estado Español y la República de Costa Rica (San José de Costa Rica, 9 de enero de 1953). Madrid: Imprenta del Ministerio de Asuntos Exteriores, 1954.

Ministerio de Relaciones Exteriores de Costa Rica. Informe de labores del Ministerio de Relaciones Exteriores. San José de Costa Rica: Imprenta Nacional, 1949.

Molinero, Carme - Ysás, Pere. La anatomía del franquismo. De la supervivencia a la agonía, 1945-1977. Barcelona: Crítica, 2008.

Moradiellos, Enrique. Francisco Franco: crónica de un caudillo casi olvidado. Madrid: Biblioteca Nueva, 2002.

Naciones Unidas. Documentos oficiales del segundo periodo de sesiones de la Asamblea General, Resoluciones, 16 de septiembre-20 de noviembre de 1947. New York: Lake Success, 1947.

- Actos resumidos de las sesiones del 5 de abril y 13 de mayo de 1949. New York: Lake Success, 1949a.

- Asamblea General. Asuntos Políticos y de Seguridad. Actas de abril y mayo de 1949. New York: Lake Success, 1949 b.

- Documentos oficiales del $5^{\circ}$ periodo de sesiones de la Asamblea General, vol. I, 19 de septiembre-15 de diciembre de 1950. New York: Lake Success, 1950a.

- Resoluciones aprobadas por la Asamblea General durante el periodo comprendido entre el 19 de septiembre y el 15 de diciembre de 1950. New York: Lake Success, $1950 b$.

Pardo Rosa, María. ¡Con Franco hacia el Imperio!: la politica exterior española en América Latina, 1939-1945. Madrid: Universidad Nacional de Educación a Distancia, 1995.

Pereira, Juan Carlos. Introducción al estudio de la política exterior de España (siglos XIX y XX). Madrid: Akal, 1982.

Pérez Brignoli, Héctor. Breve historia contemporánea de Costa Rica. México: Fondo de Cultura Económica, 1997.

Pons Ràfols, Xavier (coord.). España y la ONU: 50’aniversario. Barcelona: Icaria Editorial, 2005.

Portero, Florentino. Franco aislado. La cuestión española (1945-1950). Madrid: Aguilar, 1989.

Preston, Paul. Franco: caudillo de España. Barcelona. Círculo de Lectores, 1994.

Ríos, Ángel María. Costa Rica y la Guerra Civil española. San José: Editorial Porvenir, 1997.

Sáenz Carbonell, Jorge Francisco. "150 años de relaciones Hispano-Costarricenses (1850-2000)". En Costa Rica y España: 150 años de amistad, editado por Agencia Española de Cooperación Internacional. Madrid: AECI-Embajada de Costa 
Rica, 2000.

- Historia diplomática de Costa Rica (1948-1970). Heredia: Escuela de Relaciones Internacionales, 2013.

Saz, Ismael. Fascismo y franquismo. Valencia: Universitat de València, 2004.

Serra Puche, Mary Carmen - Mejía Flores, Francisco - Sola Ayape, Carlos (coords.). 1945, entre la euforia y la esperanza: el México posrevolucionario y exilio republicano español. México: Fondo de Cultura Económica-UNAM, 2014.

Sola Ayape, Carlos. Entre fascistas y cuervos rojos: España y México (1934-1975). México: Editorial Porrúa-Tecnológico de Monterrey, 2008.

- "A ganar la Guerra Civil española: México contra Franco en la Conferencia de San Francisco de 1945". Casa del Tiempo, vol. II, época IV, n 24 (2009), 153159.

_ "El régimen presidencialista mexicano ante el primer franquismo (1939-1955)". En Ruptura y transición: España y México, 1939, editado por Sánchez Andrés, Agustín - Mateos, Abdón. Madrid: Eneida, 2011, 185-212.

- "México y el principio de universalidad: en torno al ingreso de España en la ONU en 1955". Historia del Presente, n² 24, II época (2014), 157-173.

— "América Latina ante la Spanish question: el régimen franquista como eje de la discordia en la ONU (1945-1950)". Latinoamérica. Revista de Estudios Latinoamericanos, $\mathrm{n}^{\mathrm{o}} 61$ (2015), 65-95.

- (coord.). Los diplomáticos mexicanos y la Segunda República Española (19311975). Madrid: Fondo de Cultura Económica, 2016a.

— "De Cárdenas a Echeverría: los 12 puntos de la política exterior de México hacia la España de Franco (1936-1975) ', Foro Internacional, no 224, vol. 56 (2) (2016b), 321-377.

Tusell, Javier. La dictadura de Franco. Barcelona: Altaya, 1996.

Viñas, Ángel. Política comercial exterior en España (1931-1975). Madrid: Banco Exterior de España, 1979. 